\title{
Successful Treatment of Severe Gamma- Hydroxybutyric Acid Withdrawal Syndrome With Dantrolene
}

\author{
Anna Eveline Röell ${ }^{1}$, Dharmanand Ramnarain ${ }^{2,} 3$, Rama Kamal ${ }^{4}$ \\ 1. Intensive Care Medicine, Radboud University Medical Center, Nijmegen, NLD 2. Intensive Care Medicine, \\ Saxenburgh Medisch Centrum, Hardenberg, NLD 3. Intensive Care Medicine, Elisabeth-TweeSteden Ziekenhuis, \\ Tilburg, NLD 4. Psychiatry, GGzE, Eindhoven, NLD
}

Corresponding author: Dharmanand Ramnarain,dhar_ram@hotmail.com

\begin{abstract}
The prevalence of gamma-butyrolactone/gamma-hydroxybutyric acid (GBL/GHB) use is increasing. The gravity and number of incidents with this drug are relatively high. A feared complication is addiction and its withdrawal syndrome, which can be life-threatening and is difficult to treat. We present the case of a 31year-old man, admitted to the ICU because of accidental GBL withdrawal. The patient was tachycardic, sweaty, extremely agitated, and showed signs of psychosis. High doses of benzodiazepines, propofol, sufentanil, and quetiapine could not sedate the patient sufficiently. Dosing with pharmaceutical GHB was challenging due to severe gastric retention. As the patient developed hyperthermia and rhabdomyolysis, signs of a neuroleptic malignant syndrome (NMS), he was treated with dantrolene. After 14 days, the patient was discharged to a psychiatric clinic for further treatment. GHB affects multiple neurotransmitters and chronic use causes the up- or down-regulation of several receptors. During GHB withdrawal, the patient developed a hyperexcitable state, in which there was insufficient gamma-aminobutyric acid (GABA) (the most important inhibiting neurotransmitter) and an abundance of glutamate (the most important excitatory neurotransmitter). High-dose benzodiazepines are often advocated as the first-line treatment, but benzodiazepine resistance has frequently been reported. Therefore, treatment with pharmaceutical GHB is advised. Patients with GHB-withdrawal who have clinical signs of NMS can be treated with dantrolene because it regulates the distorted calcium secretion and affects the serotonin and cholinergic system.
\end{abstract}

Review began 06/28/2021 Review ended 07/04/2021 Published 07/14/2021

\section{() Copyright 2021}

Röell et al. This is an open access article distributed under the terms of the Creative Commons Attribution License CC-BY 4.0., which permits unrestricted use, distribution, and reproduction in any medium, provided the original author and source are credited.
Categories: Emergency Medicine, Internal Medicine, Psychiatry

Keywords: ghb, detoxification, pharmaceutical ghb, dantrolene, neuroleptic malignant syndrome

\section{Introduction}

Gamma-butyrolactone (GBL) is a drug that is growing in popularity among young adults and adolescents [1]. GBL is an industrial solvent that is rapidly absorbed and metabolized into its active metabolite gammahydroxybutyric (GHB) acid. GHB has an anxiolytic, hypnotic, and euphoric effect [1]. The effect of GBL is 2.5 times stronger than that of GHB because of its biological availability, but it is always metabolized into GHB to have a clinical effect.

The most recent epidemiological data of GHB consumption originates from the Netherlands, where $0.4 \%$ of adults reported using GHB in the past year [2,3]. However, the prevalence of GHB use in partying adolescents is $14 \%$ and the number of GHB users that are undergoing detox treatment is rising [2-4]. The gravity and number of GHB-related incidents are relatively high. In 2017, 4.7\% of all ICU admissions were due to drug intoxication; in $22 \%$ of all drug incidents (not only ICU), GHB use was reported [3,5].

Complications of GHB use include addiction, withdrawal, acute toxicity, and a serious risk of fatal overdose $[6,7]$. GHB withdrawal syndrome is difficult to treat and a high percentage of patients relapse over time [7]. Due to these complications and the presence of pre-existent psychiatric and other diseases, the costs associated with the admission of GHB-intoxicated patients to the ICU are higher than any other patients $[3,8]$.

Symptoms of GHB withdrawal are agitation, tremors, tachycardia, insomnia, delirium, autonomic dysregulation, myoclonus, seizures, rhabdomyolysis, liver and kidney failure, and hallucinations, which can develop into an excited delirium [9]. In particular, the latter can be life-threatening. Symptoms of detoxification can arise within 6 to 76 hours after the cessation of chronic GHB use and can persist for 48 hours to 15 days. Months thereafter, symptoms of delirium, psychosis, and/or depression can persist [10]. With GBL use, withdrawal symptoms can arise earlier and be more severe. It is important to start the treatment of GHB withdrawal immediately: the risk of complications is higher when you wait longer [11].

Treatment of GHB withdrawal has not been properly researched [7,12]. High doses of benzodiazepines are usually advocated, but benzodiazepine resistance in GHB withdrawal is relatively common and pharmaceutical GHB is considered the first-line treatment of GHB detoxification [6,7,13]. Medications that can have an additional effect are baclofen, barbiturates, gabapentin, and propofol. Low-dose antipsychotics 
can be used with caution because they can cause neuroleptic malignant syndrome (NMS) in patients with GHB withdrawal syndrome [14].

We describe the case of a patient admitted to the ICU because of accidental GBL detoxification. Dantrolene was used to treat hyperthermia and rhabdomyolysis.

\section{Case Presentation}

A 31-year-old man was admitted to the orthopedic department because of an ankle fracture that needed surgical treatment (osteosynthesis). Two days after surgery, he was admitted to the ICU because of severe agitation and psychotic symptoms (i.e., agitation, suspiciousness, delusions, and hallucinations). He had a history of GBL and cocaine abuse. His medical history was unremarkable with no use of medication. Physical examination revealed an extremely agitated patient with sinus tachycardia of 130 beats per minute and a temperature of $39.9^{\circ} \mathrm{C}$. Initial laboratory tests showed leucocytes 3.7 E9/L, creatinine kinase (CK) 939 IU/L, urea $10.3 \mathrm{mmol} / \mathrm{L}$, and creatinine $106 \mu \mathrm{mol} / \mathrm{L}$. In the absence of sepsis, hypothyroidism, statin use, or other toxic medication, we diagnosed a GHB withdrawal syndrome based on his history. He had previously kept his GBL use secret and had not used GBL for over 24 hours.

He was treated with high doses of benzodiazepines and antipsychotics. Because of the resulting respiratory depression, he was intubated and mechanically ventilated. Despite high levels of lorazepam 2 mg Q4H, continuous infusion of midazolam $5 \mathrm{mg} /$ hour, propofol $2.9 \mathrm{mg} / \mathrm{kg} /$ hour, sufentanil $10 \mu \mathrm{g} /$ hour, quetiapine $100 \mathrm{mg}$ Q4H, and GHB $2250 \mathrm{mg} \mathrm{Q} 2 \mathrm{H}$, it was difficult to achieve adequate sedation. The concentration of GBL that the patient used at home was calculated using liquid chromatography with tandem mass spectrometry (LC-MS/MS) and was almost 100\% pure. We estimated this to be seven times stronger than our pharmaceutical GHB-dosage (150 mg/mL) with an additional 2.5 times higher biological availability of GBL in comparison to GHB. Despite this knowledge, titrating pharmaceutical GHB was challenging due to severe gastric retention in the first five ICU days despite the prescription of prokinetic medication.

Hyperthermia persisted without any evidence of bacterial infection. His temperature rose to $41.5^{\circ} \mathrm{C}$ and his CK values increased to 33.360 IU/L. Malignant hyperthermia was ruled out in the absence of generalized rigidity. To prevent further deterioration, the patient was cooled therapeutically to temperatures under $39.0^{\circ} \mathrm{C}$. Despite cooling and broad-spectrum antibiotics, high levels of CK persisted. Because of suspected quetiapine-induced pyrexia, in combination with possible quetiapine accumulation due to erythromycininduced CYP3A4 inhibition, the administration of quetiapine and erythromycin was ceased. However, in the following days, hyperthermia and rhabdomyolysis persisted. To treat the persisting hyperthermia and rhabdomyolysis, off-label treatment with dantrolene $4 \mathrm{mg} / \mathrm{kg} /$ day was started on day 7 . During treatment, the patient's temperature normalized and CK levels declined dramatically within two days. After four days, dantrolene was stopped and there was no indication for treatment with benzodiazepines, antipsychotics, propofol, and/or sufentanil. The patient woke with no agitation and could be weaned from the ventilator. After 14 days, he was transferred to a psychiatric clinic.

\section{Discussion}

GBL is a GHB precursor. GHB is an endogenous neurotransmitter and neuromodulator that influences neuroprotective mechanisms and deep sleep [15]. Endogenous GHB is made from gamma-aminobutyric acid (GABA), the most important inhibiting neurotransmitter. Exogenous GHB overloads the endogenous GHB system, causing an increase in GABA, reinforcing its inhibiting effect [16].

The use of GHB causes a dose-dependent biphasic effect (Table 1). Initially, there is a stimulant-like effect, followed by a mixture of sedation and a stimulant-like effect. In a low dose, GHB has an additional effect on endogenous GHB. This leads to negative feedback on GABA, thereby causing the drug user to feel euphoric. In higher doses, GHB also stimulates the GHB- and the GABA-A receptor, causing an increase in GABA and therefore a sedating effect $[6,7]$. It also directly affects the GABA-B receptor, causing an increase in dopamine, thus leading to a stimulating or inhibiting effect depending on the location of the receptor. Chronic use causes GHB tolerance due to lower endogenous GABA and dopamine production and upregulation of dopamine (D1 and D2) receptors. When chronic GHB use is ceased, there is too little GABA to stimulate the desensitized receptors, which causes insomnia and anxiety. A few hours after cessation, the inhibition of dopamine is reversed, causing an acute rise in dopamine concentration. This could lead to psychosis $[6,7]$.

\begin{tabular}{|c|c|c|c|c|c|c|}
\hline \multicolumn{3}{|c|}{ GHB/GBL use } & \multicolumn{2}{|c|}{ GHB/GBL detoxification } & \multirow[b]{2}{*}{ Clinical effect } & \multirow[b]{2}{*}{ Treatment } \\
\hline Receptor & Neurotransmitter effect & $\begin{array}{l}\text { Clinical } \\
\text { effect }\end{array}$ & Chronic use & $\begin{array}{l}\text { Neurotransmitter } \\
\text { effect }\end{array}$ & & \\
\hline \multicolumn{7}{|c|}{ Direct effect } \\
\hline & & Deep sleep, & Tolerance, less & Shortness of & & \\
\hline
\end{tabular}




\section{Cureus}

\begin{tabular}{|c|c|c|c|c|c|c|}
\hline GHBR & Increased GABA levels & $\begin{array}{l}\text { rewards } \\
\text { memory }\end{array}$ & $\begin{array}{l}\text { endogenous } \\
\text { GABA }\end{array}$ & GABA & Insomnia & Barbiturates \\
\hline $\begin{array}{l}\text { GABA-A } \\
\mathrm{R}^{\star}\end{array}$ & Increased GABA levels & $\begin{array}{l}\text { Sleep, } \\
\text { decreased } \\
\text { anxiety }\end{array}$ & $\begin{array}{l}\text { Tolerance, less } \\
\text { endogenous } \\
\text { GABA }\end{array}$ & $\begin{array}{l}\text { Shortness of } \\
\text { GABA }\end{array}$ & Insomnia, anxiety & $\begin{array}{l}\text { Benzodiazepines, } \\
\text { propofol }\end{array}$ \\
\hline $\begin{array}{l}\text { GABA-B } \\
R\end{array}$ & Increased dopamine levels & $\begin{array}{l}\text { Addiction, } \\
\text { stimulating } \\
\text { and } \\
\text { inhibiting } \\
\text { effects }\end{array}$ & $\begin{array}{l}\text { Tolerance, less } \\
\text { endogenous } \\
\text { dopamine }\end{array}$ & $\begin{array}{l}\text { Acute rise of } \\
\text { dopamine levels }\end{array}$ & $\begin{array}{l}\text { Psychosis, delirium, } \\
\text { hypertension, } \\
\text { sleeplessness, agitation, } \\
\text { paranoia, disorientation, } \\
\text { confusion, aggression, } \\
\text { hallucinations }\end{array}$ & Baclofen \\
\hline \multicolumn{7}{|c|}{ Indirect effect } \\
\hline \multirow{3}{*}{ GHBR } & \multirow[t]{2}{*}{ Higher serotonin turnover } & \multirow[t]{2}{*}{ Euphoria } & $\begin{array}{l}\text { Dopamine } \\
\text { tolerance }\end{array}$ & $\begin{array}{l}\text { Acute rise of } \\
\text { dopamine levels }\end{array}$ & $\begin{array}{l}\text { Psychosis, delirium, } \\
\text { hypertension, } \\
\text { sleeplessness, agitation, } \\
\text { paranoia, disorientation, } \\
\text { confusion, aggression, } \\
\text { hallucinations }\end{array}$ & \\
\hline & & & $\begin{array}{l}\text { Less } \\
\text { noradrenaline } \\
\text { and } \\
\text { acetylcholine }\end{array}$ & $\begin{array}{l}\text { More } \\
\text { noradrenaline } \\
\text { and } \\
\text { acetylcholine }\end{array}$ & $\begin{array}{l}\text { Tremors, miosis, sweating, } \\
\text { tachycardia, palpitations, } \\
\text { dyspnea, nausea, vomiting, } \\
\text { diarrhea, anxiety, } \\
\text { restlessness }\end{array}$ & \\
\hline & $\begin{array}{l}\text { Stimulation of growth } \\
\text { hormone }\end{array}$ & Deep sleep & Unknown & $\begin{array}{l}\text { Less growth } \\
\text { hormone }\end{array}$ & Insomnia & \\
\hline \multirow[t]{2}{*}{$\begin{array}{l}\text { GABA-A } \\
R\end{array}$} & $\begin{array}{l}\text { Less noradrenaline and } \\
\text { acetylcholine }\end{array}$ & Less anxiety & $\begin{array}{l}\text { Less } \\
\text { noradrenaline } \\
\text { and } \\
\text { acetylcholine }\end{array}$ & $\begin{array}{l}\text { More } \\
\text { noradrenaline } \\
\text { and } \\
\text { acetylcholine }\end{array}$ & $\begin{array}{l}\text { Tremors, miosis, sweating, } \\
\text { tachycardia, palpitations, } \\
\text { dyspnea, nausea, vomiting, } \\
\text { diarrhea, anxiety, } \\
\text { restlessness }\end{array}$ & \\
\hline & More neurosteroids ${ }^{\star \star}$ & Less anxiety & $\begin{array}{l}\text { Upregulation } \\
\text { neurosteroid } \\
\text { receptor }\end{array}$ & $\begin{array}{l}\text { No effect of } \\
\text { neurosteroids }\end{array}$ & Anxiety, hyperalgesia & \\
\hline \multirow{6}{*}{$\begin{array}{l}\text { GABA-B } \\
R\end{array}$} & $\begin{array}{l}\text { Decreased glutamate } \\
\text { response of nucleus } \\
\text { accumbens }\end{array}$ & $\begin{array}{l}\text { Reward and } \\
\text { stimulating } \\
\text { effect }\end{array}$ & $\begin{array}{l}\text { Tolerance of } \\
\text { GABA-B } \\
\text { receptor }\end{array}$ & $\begin{array}{l}\text { Increase } \\
\text { glutamate, } \\
\text { downregulation } \\
\text { of NMDAR }\end{array}$ & Agitation, restlessness & \\
\hline & \multirow[t]{2}{*}{ Higher serotonin turnover } & \multirow[t]{2}{*}{ Euphoria } & $\begin{array}{l}\text { Dopamine } \\
\text { tolerance }\end{array}$ & $\begin{array}{l}\text { Acute rise of } \\
\text { dopamine levels }\end{array}$ & $\begin{array}{l}\text { Psychosis, delirium, } \\
\text { hypertension, } \\
\text { sleeplessness, agitation, } \\
\text { paranoia, disorientation, } \\
\text { confusion, aggression, } \\
\text { hallucinations }\end{array}$ & Baclofen \\
\hline & & & $\begin{array}{l}\text { Less } \\
\text { noradrenaline } \\
\text { and } \\
\text { acetylcholine }\end{array}$ & $\begin{array}{l}\text { More } \\
\text { noradrenaline } \\
\text { and } \\
\text { acetylcholine }\end{array}$ & $\begin{array}{l}\text { Muscle contractions, } \\
\text { seizures }\end{array}$ & $\begin{array}{l}\text { B-blockers, } \\
\text { dantrolene }\end{array}$ \\
\hline & $\begin{array}{l}\text { Less noradrenaline and } \\
\text { acetylcholine }\end{array}$ & Less anxiety & $\begin{array}{l}\text { Less } \\
\text { noradrenaline } \\
\text { and } \\
\text { acetylcholine }\end{array}$ & $\begin{array}{l}\text { More } \\
\text { noradrenaline } \\
\text { and } \\
\text { acetylcholine }\end{array}$ & $\begin{array}{l}\text { Tremors, miosis, sweating, } \\
\text { tachycardia, palpitations, } \\
\text { dyspnea, nausea, vomiting, } \\
\text { diarrhea, anxiety, } \\
\text { restlessness }\end{array}$ & B-blockers \\
\hline & $\begin{array}{l}\text { Stimulation of growth } \\
\text { hormone }\end{array}$ & Deep sleep & Unknown & $\begin{array}{l}\text { Less growth } \\
\text { hormone }\end{array}$ & Insomnia & \\
\hline & & Addiction, & Upregulation of & Acute rise in & $\begin{array}{l}\text { Psychosis, delirium, } \\
\text { hypertension, } \\
\text { sleeplessness, agitation, }\end{array}$ & \\
\hline
\end{tabular}




\section{Cureus}

\begin{tabular}{|c|c|c|c|c|c|c|}
\hline \multirow{3}{*}{$\begin{array}{l}\text { D1 R (via } \\
\text { NMDAR) }\end{array}$} & $\begin{array}{l}\text { More glutamate in the ventral } \\
\text { tegmentum }\end{array}$ & $\begin{array}{l}\text { reward } \\
\text { memory, } \\
\text { stimulating } \\
\text { effect }\end{array}$ & $\begin{array}{l}\text { D1 and D2 } \\
\text { receptors }\end{array}$ & dopamine levels & $\begin{array}{l}\text { paranoia, disorientation, } \\
\text { confusion, aggression, } \\
\text { hallucinations }\end{array}$ & Baclofen \\
\hline & & & $\begin{array}{l}\text { Downregulation } \\
\text { of NMDAR }\end{array}$ & $\begin{array}{l}\text { Increase in } \\
\text { glutamate levels }\end{array}$ & Craving & - \\
\hline & More neurosteroids* & Less anxiety & $\begin{array}{l}\text { Upregulation of } \\
\text { neurosteroid } \\
\text { receptor }\end{array}$ & $\begin{array}{l}\text { No effect of } \\
\text { neurosteroids }\end{array}$ & Anxiety, hyperalgesia & - \\
\hline \multirow{2}{*}{$\begin{array}{l}\text { Unknown } \\
\text { receptor }\end{array}$} & $\begin{array}{l}\text { Decreased activity of the } \\
\text { hypothalamic-pituitary- } \\
\text { adrenal (HPA) axis, fewer } \\
\text { stress hormones, and more } \\
\text { oxytocin }\end{array}$ & $\begin{array}{l}\text { Less anxiety } \\
+ \text { effect on } \\
\text { dopamine } \\
\text { system }\end{array}$ & $\begin{array}{l}\text { Chronic } \\
\text { activation of } \\
\text { the HPA axis }\end{array}$ & $\begin{array}{l}\text { More stress } \\
\text { hormones and } \\
\text { less oxytocin }\end{array}$ & Anxiety & - \\
\hline & $\begin{array}{l}\text { More endogenous opioid } \\
\text { production }\end{array}$ & $\begin{array}{l}\text { Sedation, } \\
\text { analgesia }\end{array}$ & $\begin{array}{l}\text { More } \\
\text { endogenous } \\
\text { opioid release }\end{array}$ & $\begin{array}{l}\text { Less } \\
\text { endogenous } \\
\text { opioids }\end{array}$ & Hyperalgesia & Opiates \\
\hline
\end{tabular}

TABLE 1: The effect of exogenous GHB on neurotransmitters and behavior.

${ }^{*}$ R: Receptor

${ }^{* *}$ Neurosteroids are endo- or exogenous steroids that affect the threshold potential of neurons.

D1R: Dopamine D1; GABA: Gamma-aminobutyric acid; GBL: gamma-butyrolactone; GHB: gamma-hydroxybutyric acid; GHBR: GHB receptor; NMDAR: N-methyl-D-aspartate receptor.

Indirectly, GHB influences serotonin, growth hormone, glutamate, the cholinergic system, neurosteroids, and endogenous opioids, causing a euphoric, anxiolytic, analgesic, and sedative effect. Chronic use causes the chronic activation of these neurotransmitters, leading to dopamine tolerance, less cholinergic activity, more endogenous opioid release, the upregulation of neurosteroid and dopamine (D1 and D2) receptors, and downregulation of the N-methyl-D-aspartate (NMDA) receptor. The cessation of chronic GHB use, therefore, causes an imbalance of the dopamine-, cholinergic- and endogenous opioid system. Then withdrawal symptoms such as tremors, tachycardia, hypertension, hyperalgesia, hallucinations, and psychosis can arise [6,7].

Current treatment strategies mostly focus on the GABA-A receptor (benzodiazepines). However, recent studies show that the effect of GHB is mostly mediated by the GABA-B receptor and specific GABA-A receptors that are unaffected by benzodiazepines, making patients resistant to this treatment [17]. By targeting other receptors, withdrawal symptoms can be treated. Antipsychotics block dopamine receptors, but these can work counterproductively in the first phase of withdrawal as mentioned earlier. They can cause NMS syndrome by acutely depleting the brain of dopamine [18]. This could also have been the reason for our patient's hyperthermia and rhabdomyolysis. Patients can also be symptomatically treated with betablockers, which antagonize the increased cholinergic activity. The effect of GABA can be lengthened by administering barbiturates and baclofen is a GABA-B receptor agonist, causing dopamine upregulation and glutamate stabilization and thus less anxiety and agitation.

During withdrawal, patients can experience motoric restlessness or seizures due to dysregulation of the serotonin and cholinergic system and calcium streams $[6,7,19]$. It can even lead to hyperthermia and rhabdomyolysis, clinically resembling NMS or malignant hyperthermia $[6,7]$. Then, muscle relaxation with dantrolene is one of the appointed treatments [18]. Dantrolene works by inhibiting calcium secretion of the sarcoplasmic reticulum of the musculoskeletal cell, preventing muscle contraction and heat production [20]. Therefore, dantrolene can be used in patients with GHB withdrawal that have clinical signs of NMS.

\section{Conclusions}

The effects of GHB and GHB withdrawal on the brain are very complex, as it influences multiple neurotransmitters. Treatment is complicated and - unlike in our case - should be started immediately. The existing literature promotes high-dose benzodiazepines as a first-line treatment for GHB detoxification. However, because of the high risk of resistance to benzodiazepines, treatment should be focused on the GABA-B receptor with baclofen or pharmaceutical GHB. Antipsychotics could negatively influence the neurological condition of patients and cause NMS. Some GHB withdrawal symptoms resemble that of NMS which can be treated with dantrolene. 


\section{Additional Information \\ Disclosures}

Human subjects: Consent was obtained or waived by all participants in this study. Conflicts of interest: In compliance with the ICMJE uniform disclosure form, all authors declare the following: Payment/services info: All authors have declared that no financial support was received from any organization for the submitted work. Financial relationships: All authors have declared that they have no financial relationships at present or within the previous three years with any organizations that might have an interest in the submitted work. Other relationships: All authors have declared that there are no other relationships or activities that could appear to have influenced the submitted work.

\section{References}

1. Carter LP, Pardi D, Gorsline J, Griffiths RR: Illicit gamma-hydroxybutyrate (GHB) and pharmaceutical sodium oxybate $\left(\right.$ Xyrem $\left.^{\circledR}\right)$ : differences in characteristics and misuse. Drug Alcohol Depend. 2009, 104:1-10. 10.1016/j.drugalcdep.2009.04.012

2. CAM: Risicoschatting Gamma-Hydroxyboterzuur 2011: Bilthoven. 2011. https://www.rivm.nl/bibliotheek/digitaaldepot/CAM_Risicoschatting_gamma_hydroxyboterzuur_2011.pdf.

3. Trimbos Instituut. Cijfers drugs: gebruik en trends . Accessed: July 19, 2020: https://www.trimbos.nl/kennis/cijfers/cijfers-drugs.

4. Van Laar M, Van Ooyen-Houben M, Cruts A, Meijer R, Croes E: Nationale Drug Monitor: NDM Annual Report. Trimbos Instituut, Utrecht; 2016. https://www.trimbos.nl/kennis/feiten-cijfers-drugs-alcoholroken/ndm-monitoring-drugsgebruik-in-nederland.

5. NICE Dataregister. https://stichting-nice.nl.

6. Kamal RM, van Noorden MS, Franzek E, Dijkstra BA, Loonen AJ, De Jong CA: The neurobiological mechanisms of gamma-hydroxybutyrate dependence and withdrawal and their clinical relevance: a review. Neuropsychobiology. 2016, 73:65-80. 10.1159/000443173

7. Kamal RM, van Noorden MS, Wannet W, Beurmanjer H, Dijkstra BA, Schellekens A: Pharmacological treatment in $\gamma$-hydroxybutyrate (GHB) and $\gamma$-butyrolactone (GBL) dependence: detoxification and relapse prevention. CNS Drugs. 2017, 31:51-64. 10.1007/s40263-016-0402-z

8. van Beusekom I, Bakhshi-Raiez F, de Keizer NF, de Lange DW: The healthcare costs of intoxicated patients who survive ICU admission are higher than non-intoxicated ICU patients: a retrospective study combining healthcare insurance data and data from a Dutch national quality registry. BMC Emerg Med. 2019, 19:6. 10.1186/s12873-019-0224-7

9. Snead OC 3rd, Gibson KM: Y-hydroxybutyric acid. N Engl J Med. 2005, 352:2721-2732. 10.1056/NEJMra044047

10. Wojtowicz JM, Yarema MC, Wax PM: Withdrawal from gamma-hydroxybutyrate, 1,4-butanediol and gammabutyrolactone: a case report and systematic review. CJEM. 2008, 10:69-74. 10.1017/s1481803500010034

11. Kamal RM, Dijkstra BA, Loonen AJ, De Jong CA: The effect of co-occurring substance use on gammahydroxybutyric acid withdrawal syndrome. J Addict Med. 2016, 10:229-235. 10.1097/ADM.0000000000000214

12. von Theobald L, Rousselet M, Cholet J, Debar H, Boels D, Victorri-Vigneau C, Grall-Bronnec M: Inpatient gamma-hydroxybutyrate detoxification: a case report describing day-to-day therapeutic management. J Addict Med. 2017, 11:231-234. 10.1097/ADM.0000000000000294

13. van Noorden MS, Kamal RM, Dijkstra BA, Mauritz R, de Jong CA: A case series of pharmaceutical gammahydroxybutyrate in 3 patients with severe benzodiazepine-resistant gamma-hydroxybutyrate withdrawal in the hospital. Psychosomatics. 2015, 56:404-409. 10.1016/j.psym.2014.03.002

14. Eiden C, Capdevielle D, Deddouche C, Boulenger JP, Blayac JP, Peyrière H: Neuroleptic malignant syndrome-like reaction precipitated by antipsychotics in a patient with gamma-butyrolactone withdrawal. J Addict Med. 2011, 5:302-303. 10.1097/ADM.0b013e3182236730

15. Mamelak M, Black J, Montplaisir J, Ristanovic R: A pilot study on the effects of sodium oxybate on sleep architecture and daytime alertness in narcolepsy. Sleep. 2004, 27:1327-1334. 10.1093/sleep/27.7.1327

16. Muller C, Viry S, Miehe M, Andriamampandry C, Aunis D, Maitre M: Evidence for a $Y$-hydroxybutyrate (GHB) uptake by rat brain synaptic vesicles. J Neurochem. 2002, 80:899-904. 10.1046/j.00223042.2002.00780.x

17. van Nieuwenhuijzen PS, McGregor IS, Chebib M, Hunt GE: Regional Fos-expression induced by $Y$ hydroxybutyrate (GHB): comparison with $\gamma$-butyrolactone (GBL) and effects of co-administration of the GABAB antagonist SCH 50911 and putative GHB antagonist NCS-382. Neuroscience. 2014, 277:700-715. 10.1016/j.neuroscience.2014.07.056

18. van Waarde JA, Muller ME, Verweg B: [Neuroleptic malignant syndrome: a life-threatening complication that can be treated effectively]. Ned Tijdschr Geneeskd. 2006, 150:2517-2520.

19. Coune P, Taleb O, Mensah-Nyagan AG, Maitre M, Kemmel V: Calcium and cAMP signaling induced by gamma-hydroxybutyrate receptor(s) stimulation in NCB-20 neurons. Neuroscience. 2010, 167:49-59. 10.1016/j.neuroscience.2010.02.009

20. Muehlschlegel S, Sims JR: Dantrolene: mechanisms of neuroprotection and possible clinical applications in the neurointensive care unit. Neurocrit Care. 2009, 10:103-115. 10.1007/s12028-008-9133-4 